\title{
Understanding Consumer Digital Consumption Behaviour in the Edge of Social Media Platforms
}

\author{
Cherouk Amr Yassin \\ College of Management and Technology, Arab Academy for Science Technology and Maritime Transport, Smart Village Campus, \\ Cairo, Egypt \\ Email: Cherouk.amr@aast.edu
}

How to cite this paper: Yassin, C. A. (2021). Understanding Consumer Digital Consumption Behaviour in the Edge of Social Media Platforms. Open Journal of Social Sciences, 9, 394-416.

https://doi.org/10.4236/jss.2021.910028

Received: September 13, 2021

Accepted: October 26, 2021

Published: October 29, 2021

Copyright $\odot 2021$ by author(s) and Scientific Research Publishing Inc. This work is licensed under the Creative Commons Attribution International License (CC BY 4.0).

http://creativecommons.org/licenses/by/4.0/

\begin{abstract}
This study aims at providing insights to the understanding of consumer behaviour which has become very complicated with the existence of the world of social media. Although research on consumer behaviour field has been seeking lately to understand the digital behaviour of the consumers. Marketers and academics risk offloading their market understanding to the algorithms, keeping marketers out of the loop, and losing the ability in understanding their consumer and their reactions. The lack of a well understanding of the consumer's perception and attitude towards social media recommended Ads generated from the Recommender Systems, may impede the ability of organizations to build a marketing orientation and may negatively influence predicted consumer response. Previous studies were restricted to explaining the evolving role of perception and attitude of Facebook recommended advertisements in the context of impulse buying behaviour. Thus, structural equational modelling was done to understand the effects of the variables under investigation. The findings revealed that impulse buying is affected by the positive attitude towards the recommended advertisings, which are influenced by both informativeness and credibility as values perceived from the recommended advertisings. This study provides some useful practical implications for the F-commerce administrators, advertisers, promoters, and consumers.
\end{abstract}

\section{Keywords}

Attitude, Consumer Behavior, Facebook, Impulse Buying, Perception, Recommended Advertisings

\section{Introduction}

The challenge being faced by all marketers today is how to influence consumers' 
purchasing behaviour in favour of their products or services. Consumer behaviour studies shed light on how consumers think, feel, use, dispose of any product or service including consumers' emotional, mental, and behavioural responses. Quester et al. (2007) defined "All marketing decisions are based on assumptions and knowledge of consumer behaviour". The field has gradually broadened to understand the consumer behaviour of the digital world especially after the COVID-19 pandemic where people are seeking to shop everything online from home and are very active in using social networks. Online shopping has been growing very fast worldwide with the current COVID pandemic, consumers are relying on it (Arrafi \& Ghabban, 2021).

There is a need for a deep understanding of the difference in the consumer behavior toward the online shopping and offline shopping.

In the past several decades and until now, brick-and-mortar stores have played an important role and a great opportunity for researchers to understand the consumer behaviour toward buying or not buying a product and all the factors that can influence the decision-making process whether planned or on impulse. Nowadays, everything has become different, the spending experience has been transformed due to a variety of collaborative aspects; the social media platforms have seen so much an important part of the consumers daily life, especially the Facebook and businesses, are increasingly investing in social media advertising (Chi, 2011; Duffett, 2015; Saxena \& Khanna, 2013).

Social media advertisings have numerous collaborative stimulators that have the potential to influence IB (Chen et al., 2016). Consumers who make spontaneous and frequently psychologically motivated purchases in response to a stimulus are known as IB consumers. In this study, IB is defined as "any purchase which a shopper makes but has not planned in advance" (Stern, 1962: p. 59). In the case of advertisings through Facebook, there is a need to consider how the perception and attitude towards advertising value of recommended ads perceived by the consumer can engage him/her for IB. In the beginning, Facebook was just a place for people to socialize, connect and share events; it was not expected for consumers to be exposed to such a massive amount of recommended advertisings through it, so any kind of purchase on Facebook can be considered as an unplanned purchase? Consequently, if proved that Facebook shopping is essentially powered by IB, so achievement in selling on Facebook will be conditional on attracting impulse buyers.

Even though Artificial Intelligence (AI) offers marketers a powerful tool that is guaranteed by particular circumstances and was able to achieve impressive results for a single campaign, it did not contribute to any organizational or managerial marketing knowledge (Kozinets \& Gretzel, 2021). Even though RS have become significant decision aids and an important element of the marketing models of many firms, the creators of the "black box" model of AI, sometimes lose control of it (Knight, 2017). RS offer recommendations of products advertisements to consumers in which they may be involved and let firms control the 
power of mutual filtering and feature based on recommendations to better serve their customers and increase sales. Research in RS has focused nearly exclusively on the enhancement and development of the algorithms that let these systems produce correct recommendations and predictions. Marketers and academics risk offloading their own market "understanding" to the algorithms, keeping marketers out of the loop, and losing the ability of a well understanding to the consumer perception and attitude towards the Facebook recommended advertisings, which will impede the ability of organizations to build a good marketing orientation (Kohli \& Jaworski, 1990) and may negatively influence the learning and human capital development of effective marketing strategies (Moorman \& Day, 2016). AI can change consumers into themes who are complicit in the commercial manipulation of their own private experience, thus declining personal control and encouraging the awareness of knowledge and control in the pointers of those who own their data (Puntoni et al., 2021).

Many academic researchers have focused on social media advertising as an effective tool in marketing communication strategies (Dao et al., 2014; Logan et al., 2012; McCarthy et al., 2014), or focused on the effect of direct social activities like networking, collaboration and sharing with friends on consumers' online shopping (Huang \& Benyoucef, 2013). Little has been done regarding consumers' psychology; perception and attitude toward recommended advertisings in F-commerce, which has produced a research gap that is worth studying given its massive business values (Chapman \& Bornstein, 1996; Chapman \& Johnson, 2002; Leong et al., 2017; Lichtenstein \& Slovic, 2006; Mussweiler \& Strack, 2000; Tversky \& Kahneman, 1974).

Senecal and Nantel (2004) show empirically that recommendations affect consumer choice. According to Cooke et al. (2002) the chance of buying a recommended product depends on the context, familiarity and information provided. In this study, these elements could be information, entertainment and credibility based on the advertising value model of Ducoffe $(1995,1996)$.

Thus, businesses need to understand the factors that influence consumer IB, to address this research gap, the purpose of this study is to examine whether there is a relation between Facebook recommended advertisings and impulse buying behaviour, we postulate that perception and attitude may be a key factor that helps to bridge this relationship. The paper is, therefore, organized as follows. First, a theoretical review of the main concepts will be used to elaborate the research model and to develop the hypotheses, hence, literature on online impulse buying behaviour. Facebook Advertisings and Recommender System, antecedents of Facebook recommended advertisings value, attitude toward Facebook recommended advertisings value. Next, a demonstration of the research methods, the description of the sampling procedure, the measures, the data collection, and the analysis used to test the research model. Then, study results and the key findings of the research are discussed. Finally, the paper provides implications as well as limitations and future research directions. 


\section{Theoretical Background}

The theoretical background of this research will start from discussing the literature that has been done in regard to the consumer impulse buying decision moving to Facebook advertising and recommender system to the proposed research model.

\subsection{Online Impulse Buying}

Consumers try to act rationally to achieve more efficiency in their decision-making, to attain more cognitive stability in their decisions, and to lower the perceived risks in future choices (Sheth \& Parvatiyar, 1995), merely this is not always achievable. Impulse behaviour is a powerful urge to buy and is based on unplanned, sudden, initiated on the spot, associated with a strong desire and feelings of pleasure (Chen, Su, \& Widjaja, 2016; Rook, 1987; Rook \& Fisher, 1995; Xiang et al., 2016). IB shows economic importance, about $\$ 4$ billion is spent annually by consumers in impulsive purchases (Liao \& Wang, 2009) with the rise of E-commerce an emergence of online IB occurs (Xiang et al., 2016).

Past research has viewed the antecedents of IB in online shopping and indicates that web characteristics, online recommendation, sales promotion, store performance and browsing arouse online IB (Chang \& Tseng, 2014; Chen et al., 2019; Lo et al., 2016; Parboteeah et al., 2009; Vonkeman et al., 2017; Wells et al., 2011; Wu et al., 2020; Xiang et al., 2016). The influences that trigger IB in social media may differ from other contexts. Because of this fact, online IB has expanded enormously, and a significant part of social commerce profits is accredited to IB (Wu et al., 2016).

Furthermore, the recent studies showed in social commerce recognized that online reviews, browsing, number of likes, design of shopping websites, price attributes of products, advertising information and marketer-generated content or stimuli, sale on a product, push notifications from mobile applications arouse online impulse purchases (Chen et al., 2016; Floh \& Madlberger, 2013; Hostler et al., 2011; Liu et al., 2013; Mulky et al., 2019; Park et al., 2012; Summers \& Hebert, 2001; Xiang et al., 2016; Xu et al., 2020; Zhang et al., 2018). A study by Chen et al. (2016) found that Facebook leads to impulsive buying because it provides tools that make buying easy, for example, RS make it easier when product advertisements automatically appear in consumers' newsfeeds; and when Facebook has extended control over the kinds of advertisements displayed; and lastly, Facebook has streamlined the process of purchasing products and services without leaving the Facebook domain.

Liu et al. (2013) stated that the online shopping atmosphere is more encouraging to IB than the offline because in online shopping consumers are free from constraints such as inconvenient locations, social pressure from staff and other consumers, limited operating hours, and lastly spreading viruses which are what consumers went through $100 \%$ during the pandemic closure. Additionally, the popularity of social media makes it easier for the consumer to finish their pur- 
chase online. Even though pandemic has confronted the basics of the expected utility theory, by stopping sellers and consumers from recognizing the possible consequences of particular decisions during the crisis. In this situation, routine rationality manages to overcome in the decision-making process, to achieve not ideal however acceptably good consequences (Dasgupta et al. 2020; Simon, 1957). Though these contradictory findings, it is required to review the degree to which consumer behaviour and consumption patterns changed to cope with the pandemics.

In the previous years, IB has significantly appeared in S-commerce and it attracted the consideration of academics in several fields. This interactive atmosphere is full of IB stimulators. However, limited research has been conducted on impulse buying in F-commerce with the focus being on the advertising value of the recommended advertisings (Leong et al., 2018). In addition to this, online product/service search and purchase is already commonplace around the world (Rehman et al., 2014) but what if the product comes without a prior search in front of the consumers and was recommended from the system, will it reflect him/her for an IB?

\subsection{Facebook Advertisings and Recommender System}

The popularity of social media has increased at a global level (Kucuk \& Krishnamurthy, 2007). Social Media Advertising is defined as "a general term capturing all forms of advertising whether explicit (banner advertising and commercial videos) or implicit (fan pages or firm-related 'tweets') that are delivered through social networking sites" (Taylor et al., 2011). Patino et al. (2012) prove that social media advertising is more attractive as it offers consumers experience sharing and quick information search. As consequence, companies have invested in advertising on social media, such as Facebook to promote their products and services (Barnes \& Mattson, 2009).

Academics in consumer behaviour, psychology and behavioural economics have found that consumers' preferences to the advertisement's medium are frequently influenced by elements when preferences are raised (Chapman \& Bornstein, 1996; Chapman \& Johnson, 2002; Lichtenstein \& Slovic, 2006; Mussweiler \& Strack, 2000; Tversky \& Kahneman, 1974). Yet, despite a growing body of literature examining social media advertisings, most of the research conducted on this field is not established clearly on a specific theory or refers to a certain model with the aim of produce testable hypotheses (Knoll, 2015, Odoom et al., 2017). According to the expectancy-value theory of Fishbein's (1963), a consumer's response varies on his/her beliefs. So, value is formulated as an objective estimation by consumers that possibly will expect consumers' reactions (Pollay \& Mittal, 1993). Babin et al. (1994) noted that value is subjective perceptions derived from external influence.

Perception is the process by which organisms explain and arrange sensation to generate a significant experience of the world (Lindsay \& Norman, 1972). Which mean, a consumer is faced with a situation or stimuli. The consumer explains 
the stimuli into something meaningful to him/her based on prior experiences. However, what a consumer interprets or realizes may be significantly different from reality. Therefore, to marketers, consumers' perceptions are much more critical than their knowledge of objective reality. Significantly, marketers and scholars recognize perception and its associated models to decide what influences influence consumers to make purchase decisions.

Facebook is one of the social media tools well-defined as a "Web-based site which bring different people together in a virtual platform and ensure a deeper social interaction, stronger community and implementation of cooperation projects" (Brown, 2009). The Facebook site was chosen as the social media recommended advertisings platform for this study. Many reasons support this choice, firstly, Facebook has great acceptance around the world with more than 1.37 billion daily active users, which makes it easy to find adequate respondents for the study (Dao et al., 2014; Hayta, 2013; Maiz et al., 2016; Melason, 2012). Furthermore, Facebook captures the largest part of social media advertisings revenues over the world (eMarketer, 2017). Facebook was introduced as a social media channel for friends to communicate through, to keep in touch and to share their life's news. Over time and with the high number of active users growing every day, recommended ads generated by the RS were introduced.

RS has developed an essential tool to introduce new products to consumers and influences what consumers buy or view online. For example, 35\% of Amazon sales are credited to recommendations (Hosanagar et al., 2014). There are many ways RS are working, firstly RS asking consumers to rate an item that they have previously experienced. Then, these ratings are used as inputs by RS. This contributes to an investigation marketplace, in which data excess is "fed into advanced manufacturing processes known as 'machine intelligence' and fabricated into prediction products that anticipate what you will do now, soon, and later" (Zuboff, 2019: p. 14). Secondly, targeted advertisements based on personality characteristics suggested from the analysis of Facebook likes in combination with online survey questions is another way and can increase conversion rates by about $50 \%$ (Matz et al., 2017).

The concept of advertising value introduced by Ducoffe (1995), as the consumers' perception of the value of the advertising based on the uses and gratifications theory (UGT) (Blumler \& Katz, 1974), which proposes that consumers select the media that most excellent satisfy their cognitive and affective needs concerning their personal needs and gratification-seeking motives. The advertising value model established by Ducoffe $(1995,1996)$ is the most extensively used theory to clarify user perceptions and attitudes toward advertising (Murillo et al., 2016). It is created on three antecedents of advertising value: informativeness, entertainment and irritation and recommended a positive link between advertising value and attitude toward advertising. Later on, irritation was removed from the model and credibility was added to the model (Brackett \& Carr Jr., 2001; Dao et al., 2014). To identify the effects of the three antecedents of ad- 
vertising value model on Facebook recommended advertisings, the concept introduced by Ducoffe (1996) will be applied:

\subsubsection{Informativeness}

Advertising informativeness is defined as the ability of advertising to inform consumers of complementary product information (Ducoffe, 1996), which allows them to make easy decisions with the "highest value" product (Rotzoll et al., 1990). Therefore, consumers purposely consider Facebook advertisements as it offers a good source of exchanging information, shows of personal contacts as well as additional product information (Dao et al., 2014; Muntinga et al., 2011). Therefore, social media users are more interested in informative advertising by social media sites as the advertisement information is viral by nature and consumer could share information and learn about the experience of other (Logan et al., 2012). Several studies stated that informativeness is a significant influence on consumers' perceived value of social media advertising, the more information the advertising offers to consumers about the products or services provided the more effect on advertisements' value (Dao et al., 2014; Saxena \& Khanna, 2013; Zeng et al., 2009) and therefore, recommended Facebook advertisement appears to a consumer as it was already recommended from the system the o information provided from the advertisement can be very valuable to consumers.

Thus, the following hypothesis is proposed:

H1. Informativeness has a positive influence on consumers' perceptions of recommended Facebook Advertising value.

\subsubsection{Entertainment}

Zhou and Bao (2002) defined advertising entertainment as the pleasure and enjoyment derived from the advertisement. Consumers are using social media to looking for fun and relaxation and their hedonic needs can easily be satisfied by offering them pleasure and enjoyment through the advertisement (Edwards et al., 2002). Social media advertising content offers consumers entertainment values that hang on the styles of the advertising (Muntinga et al., 2011; Zhang \& Mao, 2016). Furthermore, a positive relationship between perceived entertainment and the perceived value of advertising has been established by several kinds of research (Dao et al., 2014; Saxena \& Khanna, 2013). In this context, an entertainment Facebook recommended advertising can have a positive effect on consumers' advertising value perception. As consequence, advertisers try their hard to provide entertaining advertising to boost the effectiveness of their message (Hoffman \& Novak, 2012).

Thus, the following hypothesis is proposed:

$\mathrm{H} 2$. Entertainment has a positive influence on consumers' perceptions of Facebook recommended advertising value.

\subsubsection{Credibility}

Advertising credibility refers to the believability and truthfulness of the adver- 
tisement content and the expectations of consumers regarding its fairness (Logan et al., 2012; MacKenzie \& Lutz, 1989). In the social media advertising context, the content of an advertisement is measured as reliable and trustworthy from the time when comments from social connections are shown (Chu \& Kim, 2011; Okazaki, 2004). Parise and Guinan (2008) stated that users carry more positive insights about product advertising messages on social media. In this context, social media advertising is considered a credible source of product information and progressively perceived by customers (Mangold \& Faulds, 2009). According to previous studies, advertising credibility has a positive effect on web advertising value (Dao et al., 2014; Liu et al., 2012) and in the Facebook context, a positive recommended advertising credibility leads to positive perceptions of Facebook recommended advertising. Thus, the following hypothesis is proposed:

H3. Advertising credibility has a positive influence on consumers' perceptions of Facebook recommended advertising value.

\subsection{Attitude towards Facebook Recommended Advertisings Value and Impulse Buying Behaviour}

Attitude is a mental state of willingness, organized through experience, affecting the individual's response to all objects and situations to which it is related (Allport, 1935). A tendency to act in a particular way is due to both experience and personality (Pickens, 2005). A broader definition of attitude realizes it as "an enduring organization of motivational, emotional, perceptual and cognitive processes concerning some aspect of our environment" (Hawkins et al., 2004). More precisely, "attitude refers to knowledge and positive or negative feelings about an object or activity" (Dibb et al., 1991) and can similarly be seen as an "overall evaluation that expresses how much we like or dislike an object, issue, person or action” (Hoyer et al., 2001; Petty et al., 1991; Solomon, 2004).

Attitudes are shaped by four functions; Knowledge function, Value expressive function, Utilitarian function, Ego-Defensive function (Grewal et al., 2000; Katz, 1960). Attitudes are shaped by the four influences but normally a single influence can play the role (Hawkins et al., 2004). For this study, attitude will be treated as a Value expressive function, in such a way that it will be shaped by the way individuals value the recommended advertising. In this context, it is possible to advance that

H4: Recommended Facebook Value has a positive effect on consumers Attitude towards the recommended advertisings.

Mitchell and Olson (1981) show that consumers' attitudes toward advertising impact their reactions to this advertisement; a negative attitude for online advertising recognized as unpleasant and annoying produce a negative consumer's behavioural response like evading the online advertising (Li et al., 2002). In Reverse, if the consumers enjoy online advertising because it is interactive or personalized, they will develop a positive behavioural response toward it and in turn 
react positively (Logan et al., 2012; Zeng et al., 2009). Thus, based on these discussions, further investigations are needed (Bolton et al., 2013). The Theory of Reasoned Action (Fishbein et al., 1980) attempts to link a product attitude to the intention to purchase and the frequency of past purchasing and then predicting the purchase behaviour. "There is a lot of controversy on how a positive attitude towards a company or a brand can influence behaviour" (Dibb et al., 1991). Previous studies have displayed that consumers' attitudes toward social media advertising influence their responses toward it (Boateng \& Okoe, 2015; Kamal et al., 2013; Wang \& Sun, 2010).

In traditional offline contexts, prior research shows that recommendations significantly impact the decision-making process of many online consumers, Senecal and Nantel (2004) show empirically that recommendations affect consumer choice. They discover that repeatedly RS can be farther influential than human recommendations. Consumers can enjoy the outcome of decisions made by digital assistants, which effectively match personal preferences with available options without having to endure the cognitive and affective fatigue that decision making can entail (André et al., 2018) and which in turn encourage impulse buying behaviour. So, recommendation factors can be important drivers affecting consumers' impulse behaviours.

Promoters decide that people rarely go to Facebook specifically to shop (yet), so when they buy something it's an unplanned purchase, consumers engage in categorical inference making when they are served behaviorally targeted advertisings: they attribute the advertisements they receive to the advertiser labelling them as a person with specific tastes (Summers et al., 2016). For instance, Wang and Sun (2010) highlighted that favourable consumers' behavioural responses, such as clicking on the social media advertising to get further information or buying the product advertised on social media are the result of a favourable consumer's attitude toward the advertisement (Dreze \& Zufryden, 1997; Mir, 2012). From there, it is possible to advance that:

H4. favourable attitudes toward recommended Facebook advertisings affect impulse buying behaviour.

\subsection{Research Model and Framework}

Based on the previous literature review, the research model below is proposed, capturing the previously presented hypotheses where the recommended ads value perception including informativeness, entertainment and credibility are the independent variable, then attitude is the intervening variable and IB is the dependent variables. The conceptual model presents the hypothesized relations between Value, attitude, and IB (Figure 1).

\section{Methodology}

\subsection{Measurement Scales}

A well-validated measure of constructs has been adapted from previous litera- 
ture and updated with a minor modification to fit the study context. Table 1 shows the measurement scales used in the study. To measure all these constructs, a five-point Likert scale has been used. Then, a pilot study has been performed with marketing scholars and experts.

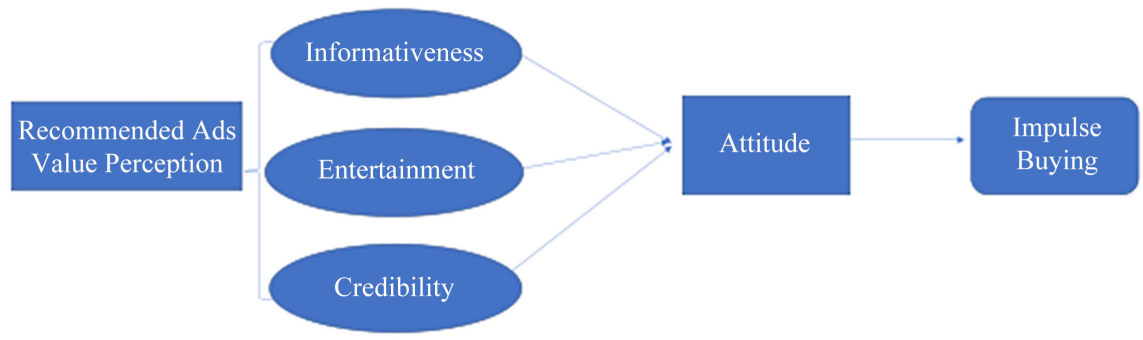

Figure 1. Proposed research model.

Table 1. Measurement scales.

\begin{tabular}{|c|c|c|}
\hline Construct & Items & Author, Year \\
\hline \multirow{3}{*}{ Informativeness } & 1-Recommended Facebook Advertising supplies relevant information on products. & \multirow{3}{*}{ Cheng et al. (2009) } \\
\hline & & \\
\hline & $\begin{array}{l}\text { 3-Recommended Facebook Advertising tells me about products when I need the } \\
\text { information. }\end{array}$ & \\
\hline \multirow{3}{*}{ Entertainment } & 1-Recommended Facebook Advertising is entertaining & \multirow{3}{*}{$\begin{array}{l}\text { Dao et al. (2014) } \\
\text { From Ducoffe's (1995) }\end{array}$} \\
\hline & 2-Recommended Facebook Advertising is enjoyable & \\
\hline & 3-Recommended Facebook Advertising is pleasing & \\
\hline \multirow{3}{*}{ Credibility } & 1-Recommended Facebook Advertising is credible & Dao et al. (2014) \\
\hline & 2-Recommended Facebook Advertising is trustworthy & \multirow{2}{*}{$\begin{array}{l}\text { From MacKenzie and Lutz } \\
\text { (1989) }\end{array}$} \\
\hline & 3-Recommended Facebook Advertising is believable & \\
\hline \multirow{3}{*}{$\begin{array}{l}\text { Recommended } \\
\text { Advertising } \\
\text { Value }\end{array}$} & 1-Recommended Facebook Advertising is valuable for me. & \multirow{3}{*}{$\begin{array}{l}\text { Adopted from Zeng et al. } \\
(2009)\end{array}$} \\
\hline & 2-Recommended Facebook Advertising is useful for me. & \\
\hline & 3-Recommended Facebook Advertising is an important source of information for me. & \\
\hline \multirow{5}{*}{$\begin{array}{l}\text { Attitude toward } \\
\text { Recommended } \\
\text { Advertising }\end{array}$} & $\begin{array}{l}\text { 1-in general, I think that Facebook recommended advertising increases the cost of } \\
\text { products. }\end{array}$ & \multirow{5}{*}{$\begin{array}{l}\text { Pollay and Mittal (1993); } \\
\text { Wang and Sun (2010) }\end{array}$} \\
\hline & 2-overall, I consider Facebook recommended advertising a good thing. & \\
\hline & 3-overall, I like Facebook recommended advertisings. & \\
\hline & 4-"I consider Facebook recommended advertising very essential." & \\
\hline & $\begin{array}{l}\text { 5-"I would describe my overall attitude toward Facebook recommended advertisings very } \\
\text { favourably." }\end{array}$ & \\
\hline \multirow{5}{*}{$\begin{array}{l}\text { Impulse Buying } \\
\text { Behavior }\end{array}$} & 1-My purchase was spontaneous. & \multirow{5}{*}{$\begin{array}{l}\text { Verhagen and } \\
\text { Van Dolen (2011) }\end{array}$} \\
\hline & 2-My purchase was unplanned. & \\
\hline & 3-I did not intend to do this purchase without the help of the Recommender System. & \\
\hline & $\begin{array}{l}\text { 4-Before seeing the recommended advertising, I did not have the intention to do this } \\
\text { purchase. }\end{array}$ & \\
\hline & 5-I could not resist to do this purchase after seeing the recommended advertising. & \\
\hline
\end{tabular}




\subsection{Sampling Techniques}

As there is no sampling frame, convenience sampling was used whereby active Facebook users of all demographics who had purchased at least once through Facebook recommended advertisings were chosen as the target population. The questionnaire was distributed in different Facebook Groups and personal accounts. All the respondents answered freely and anonymously. They were asked at the beginning to read a scenario with an attached screenshot from Facebook with the RS advertisings highlighted to make sure they understand the purpose of the study. Then a filtering question in the survey instrument was used to indicate the number of purchases done of recommended product/service by Facebook was made. Any survey with a "zero" answer to this question was removed from the analysis.

\subsection{Data Collection}

The survey was conducted in January 2021, the survey was held for one month. Overall, the survey collated a total of 605 responses, 500 of which were validated see Table 2. A total of $58 \%$ of the subjects were female and $42 \%$ were male. Most of them (65\%) were aged 19 to 28 years old, this indicates that the majority of the respondents who buy in response to Facebook recommended advertisements were between 19 - 28 years old therefore this age category, could depend on to make comprehensive conclusions about this study. In addition, most of the participants shopped three times from Facebook recommended ads (41\%), and the three main purchase product categories were determined to be clothing (38\%), electronics (20\%), grocery products (19\%) then Services (18\%) and others (5\%).

\section{Results}

Data analysis was performed using a reliability and validity analysis to ensure the internal consistency and validity two-step approach. The first step was the Cronbach's coefficient alpha by using SPSS and the second step test the measurement model through a confirmatory factor analysis was carried out on the scales to test the interrelationships among the research model using structural equation modelling analysis with AMOS 26.0 software.

\subsection{Reliability and Validity}

Cronbach's coefficient alpha was used to test the reliability of the 22 relevant variables that were used in the factor analysis. From the analysis, the standardized item (alpha) for these variables ranged from .499 to .940 was shown in Table 3. The alpha scores for each factor were more than .5 except for one item "in general, I think that Facebook recommended advertising increases the cost of products" from the attitude toward Facebook recommended advertising scale. After removing this item the construct has been changed from .499 to .795 suggesting excellent internal consistency of all constructs was greater than the acceptable threshold value of .7 (Hair et al., 2006) indicating good reliability of the retained scales structure. 
Table 2. Demographic variables.

\begin{tabular}{|c|c|c|c|}
\hline \multicolumn{2}{|l|}{ Variable } & $\mathrm{N}$ & Percentage \\
\hline \multirow{2}{*}{ Gender } & Female & 290 & $58 \%$ \\
\hline & Male & 210 & $42 \%$ \\
\hline \multirow{5}{*}{ Age } & $<19$ & 25 & $5 \%$ \\
\hline & $19-28$ & 325 & $65 \%$ \\
\hline & $29-38$ & 75 & $15 \%$ \\
\hline & $39-48$ & 50 & $10 \%$ \\
\hline & $>49$ & 25 & $5 \%$ \\
\hline \multirow{5}{*}{$\begin{array}{l}\text { How many times you purchase a product/service } \\
\text { recommended by Facebook Advertisements }\end{array}$} & Zero & $\ldots$ & All surveys were removed. \\
\hline & One & 195 & $39 \%$ \\
\hline & Two & 75 & $15 \%$ \\
\hline & Three & 205 & $41 \%$ \\
\hline & More than three & 25 & $5 \%$ \\
\hline \multirow{5}{*}{ Main purchase category } & Grocery products & 95 & $19 \%$ \\
\hline & Electronics & 100 & $20 \%$ \\
\hline & Clothing & 190 & $38 \%$ \\
\hline & Services & 90 & $18 \%$ \\
\hline & Others & 25 & $5 \%$ \\
\hline Total & & 500 & $100 \%$ \\
\hline
\end{tabular}

Table 3. Reliability of instruments.

\begin{tabular}{cccc}
\hline Scale & Number of Items & Cronbach's Alpha & Comments \\
\hline Informativeness & 3 & .940 \\
Entertainment & 3 & .873 \\
Credibility & 3 & .864 & \\
Recommended Advertising Value & 3 & .877 & The first item has been removed due to low factor loading \\
Attitude toward & 5 & .499 & and to enhance the overall value of the measurement \\
Recommended Advertising & 4 & .795 & .922 \\
Impulse buying behaviour & 5 & & \\
\hline
\end{tabular}

In attempts to confirm which items belong to what constructs and to test the construct validity of variables, Confirmatory Factorial Analysis (CFA) was conducted. Table Four presents the constructs validity results. The diagonal elements of this table report the values of the average variance extracted (AVE) for each construct. The AVE for all variables is above the suggested value of .50 (Fornell \& Larcker, 1981) implying a good convergent validity. Additionally, the discriminant validity of the research constructs was established as the AVE of each construct is greater than the squared correlations with other constructs.

\subsection{Structural Model and Hypotheses Test}

The results from the structural model are presented in Table 4. Overall, the model provides a good fit to the data with acceptable absolute, incremental, and parsimonious indices.

Based on Table 5 indicators, $H 1$ suggesting that there is a positive relationship 
between informativeness and Facebook recommended advertising value was supported. Informativeness has a positive influence on consumers' perceptions of recommended Facebook Advertising value.

Table 4. Measurement of the total construct.

\begin{tabular}{|c|c|c|c|c|c|}
\hline Question items & Construct & Factor Loading & C.R $(t)$ & Probability & SMCC \\
\hline $\begin{array}{l}\text { Recommended Facebook Advertising supplies relevant } \\
\text { information on products. }\end{array}$ & $\leftarrow$ Informativeness & 693 & N/A & N/A & .523 \\
\hline $\begin{array}{l}\text { Recommended Facebook Advertising provides timely } \\
\text { information on products. }\end{array}$ & $\leftarrow$ Informativeness & .669 & 9.072 & $* * *$ & .409 \\
\hline $\begin{array}{l}\text { Recommended Facebook Advertising tells me about } \\
\text { products when I need the information. }\end{array}$ & $\leftarrow$ Informativeness & 690 & 9.592 & $* * *$ & .410 \\
\hline \multicolumn{6}{|c|}{ Measures: RMSEA: .000; Chisq/df: .964; NFI: .997; TLI: .997; CFI: .997; AVE: .567; CR: .558 } \\
\hline Recommended Facebook Advertising is entertaining & $\leftarrow$ Entertainment & .544 & 8.052 & N/A & .496 \\
\hline Recommended Facebook Advertising is enjoyable & $\leftarrow$ Entertainment & 640 & 9.592 & $* * *$ & .410 \\
\hline Recommended Facebook Advertising is pleasing & $\leftarrow$ Entertainment & .766 & 10.854 & $* * *$ & .586 \\
\hline \multicolumn{6}{|c|}{ Measures: RMSEA: .000; Chisq/df: .964; NFI: .988; TLI: .989; CFI: .988; AVE: .538; CR: .558 } \\
\hline Recommended Facebook Advertising is credible & $\leftarrow$ Credibility & .628 & 7.262 & $\mathrm{~N} / \mathrm{A}$ & .495 \\
\hline Recommended Facebook Advertising is trustworthy & $\leftarrow$ Credibility & .626 & 7.246 & $* * *$ & .592 \\
\hline Recommended Facebook Advertising is believable & $\leftarrow$ Credibility & .568 & 6.830 & $* * *$ & .623 \\
\hline \multicolumn{6}{|c|}{ Measures: RMSEA: .000; Chisq/df: .964; NFI: .900; TLI: .910; CFI: 1.000; AVE: .638; CR: .578 } \\
\hline Recommended Facebook Advertising is valuable for me. & $\leftarrow$ Recommended Advertising Value & .535 & 6.571 & N/A & .587 \\
\hline Recommended Facebook Advertising is useful for me & $\leftarrow$ Recommended Advertising Value & .650 & 7.405 & $* * *$ & .623 \\
\hline $\begin{array}{l}\text { Recommended Facebook Advertising is an important } \\
\text { source of information for me. }\end{array}$ & $\leftarrow$ Recommended Advertising Value & .629 & 7.266 & $* * *$ & .596 \\
\hline \multicolumn{6}{|c|}{ Measures: RMSEA: .000; Chisq/df: .964; NFI: .998; TLI: .997; CFI: 1.000; AVE: .578; CR: .559 } \\
\hline $\begin{array}{l}\text { overall, I consider Facebook recommended advertising a } \\
\text { good thing. }\end{array}$ & $\begin{array}{l}\leftarrow \text { Attitude toward Recommended } \\
\text { Advertising }\end{array}$ & .719 & 7.812 & $\mathrm{~N} / \mathrm{A}$ & .516 \\
\hline overall, I like Facebook recommended advertisings". & $\begin{array}{l}\leftarrow \text { Attitude toward Recommended } \\
\text { Advertising }\end{array}$ & .578 & 6.903 & $* * *$ & .434 \\
\hline $\begin{array}{l}\text { I consider Facebook recommended advertising very } \\
\text { essential." }\end{array}$ & $\begin{array}{l}\leftarrow \text { Attitude toward Recommended } \\
\text { Advertising }\end{array}$ & .613 & 7.151 & $* * *$ & .575 \\
\hline $\begin{array}{l}\text { "I would describe my overall attitude toward Facebook } \\
\text { recommended advertisings very favourably." }\end{array}$ & $\begin{array}{l}\leftarrow \text { Attitude toward Recommended } \\
\text { Advertising }\end{array}$ & .523 & 7.876 & $* * *$ & .373 \\
\hline \multicolumn{6}{|c|}{ Measures: RMSEA: .085; Chisq/df: .964; NFI: .915; TLI: .894; CFI: .936; AVE: .639; CR: .671 } \\
\hline My purchase was spontaneous. & $\leftarrow$ Impulse buying behaviour & .731 & $\mathrm{~N} / \mathrm{A}$ & $\mathrm{N} / \mathrm{A}$ & .520 \\
\hline My purchase was unplanned. & $\leftarrow$ Impulse buying behaviour & .759 & 12.599 & $* * *$ & .554 \\
\hline $\begin{array}{l}\text { I did not intend to do this purchase without the help of } \\
\text { the Recommender System. }\end{array}$ & $\leftarrow$ Impulse buying behaviour & .818 & 11.432 & $* * *$ & .850 \\
\hline $\begin{array}{l}\text { Before seeing the recommended advertising, I did not } \\
\text { have the intention to do this purchase. }\end{array}$ & $\leftarrow$ Impulse buying behaviour & .730 & 8.877 & $* * *$ & .512 \\
\hline $\begin{array}{l}\text { I could not resist to do this purchase after seeing the } \\
\text { recommended advertising. }\end{array}$ & $\leftarrow$ Impulse buying behaviour & .770 & 8.987 & $* * *$ & .590 \\
\hline
\end{tabular}

Measures: RMSEA: .053; Chisq/df:. 121; NFI: .950; TLI: .943; CFI: .960; AVE: .545; CR: .500

Whole Model Measures: RMSEA: .052; Chisq/df: 1.531; NFI: .900; TLI: .897; CFI: .901; AVE > .5 CR: >1.97 
Table 5. Hypotheses test.

\begin{tabular}{cccccc}
\hline Construct & Construct & Estimate & S. E & C.R & Probability \\
\hline Informativeness & Value & .157 & .090 & 1.746 & $* * *$ \\
Entertaiment & Value & .082 & .093 & .880 & .379 \\
Credibility & Value & .130 & .087 & 1.498 & $* * *$ \\
Value & Attitude & .352 & .107 & 3.296 & $* * *$ \\
Attitude & IB & .451 & .136 & 3.318 & $* * *$ \\
\hline
\end{tabular}

H2 states that entertainment positively influences Facebook recommended advertising value. This relationship was not statistically significant.

$H 3$ stated that credibility has a positive influence on Facebook recommended advertising value was significant and then supported.

$H 4$ suggested that Facebook recommended advertising value positively and significantly influences consumers' attitude toward Facebook recommended advertising value. This was also statistically significant in the study.

Similarly, $H 5$ which advances a positive relationship between attitudes toward Facebook recommended advertising value and consumers' impulse buying was also significant. Thus, $\mathrm{H} 1, H 3, H 4$ and $H 5$ were statistically supported.

\section{Discussion}

The results of this study offer both theoretical and practical implications for social media advertising and impulse buying behaviour. In many consumer behaviours studies, researchers have tried to understand IB (Lim \& Yazdanifard, 2015), which is a psychologically complex phenomenon (Rook, 1987). This paper adds further insights to the effect of attitude toward recommended advertisings and its effect on IB.

\subsection{Theoretical Implications}

Based on our results, the study suggested that there is a significant impact of Recommended Facebook Advertising informativeness and credibility on consumers' perceptions of Facebook recommended advertising value which is similar to a past study that showed the chance of buying a recommended product depends on the context, familiarity and information provided (Cooke et al., 2002) and to Madhavaram and Laverie (2004) who suggested that online shopping influence IB since consumers know how to browse product information simply in the online context. In turn, advertising value has a positive influence on consumer attitude toward the Facebook recommended ad.

However, there is a significant impact from the favourable attitude towards Facebook recommended advertisements on impulse buying behaviour. This suggests that whenever consumers found a recommended advertising through Facebook there is a greater chance that they will purchase the only impulse due to a positive attitude towards the advertisings that are considered to be a good 
thing and essential to the customers. With the utmost importance of recommender systems for retailers, some research has behavioural effects of recommender systems on consumer decisions (Adomavicius et al., 2013; Jannach \& Adomavicius, 2017). Chan et al. (2017) conducted a systematic literature review on online impulse buying and only identified important external stimuli like website, marketing, and situational factors that spur behaviours. In contrast, the effects of Facebook recommended advertisings has not been fully addressed. The study also captured all the categories of age in the study, and this, therefore, confirmed that the age between 19 and 28 are mostly engaging customers for Facebook recommended advertisements.

\subsection{Marketing Implications}

In what concerns implications for practitioners, our results suggest that there is a need for more strategies to position and promote recommended products, including strategies based on making the advertising more informative and credible to the consumer. Recommended advertisings can be positive because they lead consumers to feel deeply understood either objectively or subjectively. For example, consumer categorizations can be valuable to affirm the self: personalized offers that indicate membership in an aspirational group may help consumers satisfy identity motives when they are perceived as social labels (Summers, Smith, \& Reczek 2016; Kozinets \& Gretzel, 2021) and introduce them to a new product that is needed.

Despite AI's ability to predict and satisfy preferences, consumers can feel exploited in data capture experiences, mainly because they do not understand AI's operating criteria. This can be attributed to several features of AI. First, the modalities of data acquisition are becoming increasingly intrusive and difficult to avoid. Second, even when consumers intentionally share information, they are not aware of how this information is aggregated over time and across contexts. Finally, data brokers are largely unregulated and often lack transparency and accountability (Grafanaki, 2017). Thus, as consumer behaviour becomes increasingly retailored to the exigencies of behavioural futures, educating consumers about the recommended system is needed from this side.

\subsection{Limitations and Directions for Future Research}

This study is not without limitations concerning the characteristics of research design and methodology. To begin with, the fact that we used a convenience sample must be referred to. Convenience sampling is a type of nonprobability sampling in which people are sampled because they are handy sources of data for researchers (Battaglia et al., 2008). According to Fink (2003), one of the limitations of nonprobability sampling is its susceptibility to selection biases, since all suitable respondents may not stand an equal chance of being selected as part of a sample. The study recruited all Facebook users only who had finished at least one purchase through Facebook recommended advertising, which we be- 
lieve was an important feature for selecting our unit of analysis. F-commerce will become a new paradigm of e-commerce in the next years with a potential for generating new revenues for all stakeholders. Hence, less attention has been given to the new F-commerce context, which has unavoidably formed a research gap that is worth investigating so more studies are needed to understand the impact of changes in recommendation systems on consumption behaviour in emerging markets and to what extent mimicking the practices of developed markets is adequate. Future studies may also research the effect of impulse purchasing through Facebook recommended advertisings and cognitive dissonance since a more understanding of its consequences is needed.

Furthermore, in the existing studies on e-commerce and F-commerce, the focus is mainly on purchase intention rather than impulse buying (Leong et al., 2017), a qualitative approach will be an added value to the understanding of consumer attitudes toward Facebook recommended ads Values to have a more understanding of its consequences. Models in attitude measurement to predict and understand buying behaviour is important (Fishbein, 1963) and should be applied to different types of industry.

\section{Conclusion}

To the best of our knowledge, our research was the first study to address the relationship between attitude towards Facebook recommended advertising and impulse buying behaviour. The secret to gaining sales through social media is to sell impulse products that offer instant gratification and give good value through information and credibility. However, as AI becomes global, interventions associated with how recommended advertising is presented to the consumers are needed to reduce the cognitive and affective costs associated with excessive information and choice (Chernev et al., 2015) and thereby give consumers greater control over their data without overloading them with unneeded recommendation advertisings.

\section{Conflicts of Interest}

The author declares no conflicts of interest regarding the publication of this paper.

\section{References}

Adomavicius, G., Bockstedt, J. C., Curley, S. P., \& Zhang, J. (2013). Do Recommender Systems Manipulate Consumer Preferences? A Study of Anchoring Effects. Information Systems Research, 24, 956-975. https://doi.org/10.1287/isre.2013.0497

Allport, G. W. (1935). Attitudes. In C. Murchison (Ed.), Handbook of Social Psychology (pp. 798-884). Clark University Press.

André, Q., Carmon, Z., Wertenbroch, K., Crum, A., Frank, D., Goldstein, W. et al. (2018). Consumer Choice and Autonomy in the Age of Artificial Intelligence and Big Data. Customer Needs and Solutions, 5, 28-37. https://doi.org/10.1007/s40547-017-0085-8

Arrafi, I., \& Ghabban, F. (2021). Impulse Buying Model for Business-to-Consumer 
E-Commerce in Saudi Arabia. iBusiness, 13, 81-102. https://doi.org/10.4236/ib.2021.132006

Babin, B. J., Darden, W. R., \& Griffin, M. (1994). Work and/or Fun: Measuring Hedonic and Utilitarian Shopping Value. Journal of Consumer Research, 20, 644-656. https://doi.org/10.1086/209376

Barnes, N. G., \& Mattson, E. (2009). Social Media in the 2009 Inc. 500: New Tools and New Trends. Journal of New Communication Research, 4, 70-79.

Battaglia, M., Sampling, N., \& Lavrakas, P. J. (2008). Encyclopedia of Survey Research Methods. Sage Publications.

Blumler, J. G., \& Katz, E. (1974). The Uses of Mass Communications: Current Perspectives on Gratifications Research. SAGE Publications.

Boateng, H., \& Okoe, A. F. (2015). Consumers' Attitude towards Social Media Advertising and Their Behavioural Response. Journal of Research in Interactive Marketing, 9, 299-312. https://doi.org/10.1108/JRIM-01-2015-0012

Bolton, R. N., Parasuraman, A., Hoefnagels, A., Migchels, N., Kabadayi, S., Gruber, T., Komarova Loureiro, Y., \& Solnet, D. (2013). Understanding Generation Y and Their Use of Social Media: A Review and Research Agenda. Journal of Service Management, 24, 245-267. https://doi.org/10.1108/09564231311326987

Brackett, L. K., \& Carr Jr., B. N. (2001). Cyberspace Advertising vs. Other Media: Consumer vs. Mature Student Attitudes. Journal of Advertising Research, 41, 23-32. https://doi.org/10.2501/JAR-41-5-23-32

Brown, R. (2009). Public Relations and the Social Web: How to Use Social Media and Web 2.0 in Communications. Kogan Page Publishers.

Chan, I. C. C., Lam, L. W., Chow, C. W., Fong, L. H. N., \& Law, R. (2017). The Effect of Online Reviews on Hotel Booking Intention: The Role of Reader-Reviewer Similarity. International Journal of Hospitality Management, 66, 54-65. https://doi.org/10.1016/j.ijhm.2017.06.007

Chang, C. C., \& Tseng, A. H. (2014). The Post-Purchase Communication Strategies for Supporting Online Impulse Buying. Computers in Human Behavior, 39, 393-403. https://doi.org/10.1016/j.chb.2014.05.035

Chapman, G. B., \& Bornstein, B. H. (1996). The More You Ask for, the More You Get: Anchoring in Personal Injury Verdicts. Applied Cognitive Psychology, 10, 519-540. https://doi.org/10.1002/(SICI)1099-0720(199612)10:6<519::AID-ACP417>3.0.CO;2-5

Chapman, G. B., \& Johnson, E. J. (2002). Incorporating the Irrelevant: Anchors Judgments of Belief and Value. In T. Gilovich, D. Griffin, \& D. Kahneman (Eds.), Heuristics and Biases: The Psychology of Intuitive Judgment (pp. 120-138). Cambridge University Press. https://doi.org/10.1017/CBO9780511808098.008

Chen, J. V., Su, B. C., \& Widjaja, A. E. (2016). Facebook C2C Social Commerce: A Study of Online Impulse Buying. Decision Support Systems, 83, 57-69. https://doi.org/10.1016/j.dss.2015.12.008

Chen, Y., Lu, Y., Wang, B., \& Pan, Z. (2019). How Do Product Recommendations Affect Impulse Buying? An Empirical Study on WeChat Social Commerce. Information \& Management, 56, 236-248. https://doi.org/10.1016/j.im.2018.09.002

Cheng, J. M. S., Blankson, C., Wang, E. S. T., \& Chen, L. S. L. (2009). Consumer Attitudes and Interactive Digital Advertising. International Journal of Advertising, 28, 501-525. https://doi.org/10.2501/S0265048709200710

Chernev, A., Böckenholt, U., \& Goodman, J. (2015). Choice Overload: A Conceptual Review and Meta-Analysis. Journal of Consumer Psychology, 25, 333-358. 
https://doi.org/10.1016/j.jcps.2014.08.002

Chi, H. H. (2011). Interactive Digital Advertising vs. Virtual Brand Community: Exploratory Study of User Motivation and Social Media Marketing Responses in Taiwan. Journal of Interactive Advertising, 12, 44-61. https://doi.org/10.1080/15252019.2011.10722190

Chu, S. C., \& Kim, Y. (2011). Determinants of Consumer Engagement in Electronic Word-of-Mouth (eWOM) in Social Networking Sites. International Journal of Advertising, 30, 47-75. https://doi.org/10.2501/IJA-30-1-047-075

Cooke, A. D., Sujan, H., Sujan, M., \& Weitz, B. A. (2002). Marketing the Unfamiliar: The Role of Context and Item-Specific Information in Electronic Agent Recommendations. Journal of Marketing Research, 39, 488-497. https://doi.org/10.1509/jmkr.39.4.488.19121

Dao, W. V.-T., Le, A. N. H., Cheng, J. M.-S., \& Chen, D. C. (2014). Social Media Advertising Value: The Case of Transitional Economies in Southeast Asia. International Journal of Advertising, 33, 271-294. https://doi.org/10.2501/IJA-33-2-271-294

Dasgupta, U., Jha, C. K., \& Sarangi, S. (2020). Procedural Rationality in the Time of COVID-19. Economic and Political Weekly, 55, 13-16.

Dibb, S., Simkin, L., Pride, W., \& Ferrell, D. S. (1991). Marketing Concepts and Strategies. Houghton Mifflin.

Dreze, X., \& Zufryden, F. (1997). Testing Website Design and Promotional Content. Journal of Advertising Research, 37, 77-91.

Ducoffe, R. H. (1995). How Consumers Assess the Value of Advertising. Journal of Current Issues \& Research in Advertising, 17, 1-18.

https://doi.org/10.1080/10641734.1995.10505022

Ducoffe, R. H. (1996). Advertising Value and Advertising on the Web. Journal of Advertising Research, 36, 21-35.

Duffett, R. G. (2015). Facebook Advertising's Influence on Intention-to-Purchase and Purchase amongst Millennials. Internet Research, 25, 498-526.

https://doi.org/10.1108/IntR-01-2014-0020

eMarketer Inc. (2017, July 17). eMarketer Updates Worldwide Social Network User Figures.

https://www.emarketer.com/Article/eMarketer-Updates-Worldwide-Social-Network-U ser-Figures/1016178.

Fink, A. (2003). The Survey Handbook. Sage. https://doi.org/10.4135/9781412986328

Fishbein, M. (1963). An Investigation of the Relationships between Beliefs about an Object and the Attitude toward That Object. Human Relations, 16, 233-239. https://doi.org/10.1177/001872676301600302

Fishbein, M., Jaccard, J., Davidson, A. R., Ajzen, I., \& Loken, B. (1980). Predicting and Understanding Family Planning Behaviors. In Understanding Attitudes and Predicting Social Behavior. Prentice Hall.

Floh, A., \& Madlberger, M. (2013). The Role of Atmospheric Cues in Online Impulse-Buying Behaviour. Electronic Commerce Research and Applications, 12, 425-439. https://doi.org/10.1016/j.elerap.2013.06.001

Fornell, C., \& Larcker, D. F. (1981). Structural Equation Models with Unobservable Variables and Measurement Error: Algebra and Statistics. Journal of Marketing Research, 18, 382-388. https://doi.org/10.2307/3150980

Grafanaki, S. (2017). Drowning in Big Data: Abundance of Choice, Scarcity of Attention and the Personalization Trap, a Case for Regulation. Richmond Journal of Law and 
Technology, 24, 1.

Grewal, R., Mehta, R., \& Kardes, F. R. (2000). The Role of the Social Identity Function of Attitudes in Consumer Innovativeness and Opinion Leadership. Journal of Economic Psychology, 21, 233-252. https://doi.org/10.1016/S0167-4870(00)00003-9

Hair, J. F., Black, W. C., Babin, B. J., Anderson, R. E., \& Tatham, R. (2006). Multivariate Data Analysis. Pearson Prentice Hall.

Hawkins, D. I., Best, R. J., \& Coney, K. A. (2004). Customer Behaviour: Building Marketing Strategy. McGraw-Hill.

Hayta, A. B. (2013). A Study on the Effects of Social Media on Young Consumers' Buying Behaviours. European Journal of Research on Education, 1, 65-74.

Hoffman, D. L., \& Novak, T. (2012). Why Do People Use Social Media? Empirical Findings and a New Theoretical Framework for Social Media Goal Pursuit. https://doi.org/10.2139/ssrn.1989586

Hosanagar, K., Fleder, D., Lee, D., \& Buja, A. (2014). Will the Global Village Fracture into Tribes? Recommender Systems and Their Effects on Consumer Fragmentation. Management Science, 60, 805-823. https://doi.org/10.1287/mnsc.2013.1808

Hostler, R. E., Yoon, V. Y., Guo, Z., Guimaraes, T., \& Forgionne, G. (2011). Assessing the Impact of Recommender Agents on Online Consumer Unplanned Purchase Behaviour. Information \& Management, 48, 336-343. https://doi.org/10.1016/j.im.2011.08.002

Hoyer, W. D., MacInnis, D. J., \& Pieters, R. (2001). Consumer Behaviour. Houghton Mifflin.

Huang, Z., \& Benyoucef, M. (2013). From E-Commerce to Social Commerce: A Close Look at Design Features. Electronic Commerce Research and Applications, 12, 246-259. https://doi.org/10.1016/j.elerap.2012.12.003

Jannach, D., \& Adomavicius, G. (2017). Price and Profit Awareness in Recommender Systems. arXiv preprint arXiv:1707.08029

Kamal, S., Chu, S. C., \& Pedram, M. (2013). Materialism, Attitudes, and Social Media Usage and Their Impact on Purchase Intention of Luxury Fashion Goods among American and Arab Young Generations. Journal of Interactive Advertising, 13, 27-40. https://doi.org/10.1080/15252019.2013.768052

Katz, D. (1960). The Functional Approach to the Study of Attitudes. Public Opinion Quarterly, 24, 163-204. https://doi.org/10.1086/266945

Knight, W. (2017, April 11). The Dark Secret at the Heart of AI: No One Really Knows How the Most Advanced Algorithms Do What They Do. That Could Be a Problem. MIT Technology Review.

Knoll, A. H. (2015). Life on a Young Planet: The First Three Billion Years of Evolution on Earth-Updated Edition (Vol. 87). Princeton University Press. https://doi.org/10.1515/9781400866045

Kohli, A. K., \& Jaworski, B. J. (1990). Market Orientation: The Construct, Research Propositions, and Managerial Implications. Journal of Marketing, 54, 1-18. https://doi.org/10.1177/002224299005400201

Kozinets, R. V., \& Gretzel, U. (2021). Commentary: Artificial Intelligence: The Marketer's Dilemma. Journal of Marketing, 85, 156-159.

https://doi.org/10.1177/0022242920972933

Kucuk, S. U., \& Krishnamurthy, S. (2007). An Analysis of Consumer Power on the Internet. Technovation, 27, 47-56. https://doi.org/10.1016/j.technovation.2006.05.002

Leong, L. Y., Jaafar, N. I., \& Ainin, S. (2018). The Effects of Facebook Browsing and Usage Intensity on Impulse Purchase in f-Commerce. Computers in Human Behavior, 
78, 160-173. https://doi.org/10.1016/j.chb.2017.09.033

Leong, L. Y., Jaafar, N. I., \& Sulaiman, A. (2017). Understanding Impulse Purchase in Facebook Commerce: Does Big Five Matter? Internet Research, 27, 786-818. https://doi.org/10.1108/IntR-04-2016-0107

Li, H., Edwards, S. M., \& Lee, J. H. (2002). Measuring the Intrusiveness of Advertisements: Scale Development and Validation. Journal of Advertising, 31, 37-47. https://doi.org/10.1080/00913367.2002.10673665

Liao, J., \& Wang, L. (2009). Face as a Mediator of the Relationship between Material Value and Brand Consciousness. Psychology \& Marketing, 26, 987-1001. https://doi.org/10.1002/mar.20309

Lichtenstein, S., \& Slovic, P. (Eds.) (2006). The Construction of Preference. Cambridge University Press. https://doi.org/10.1017/CBO9780511618031

Lim, P. L., \& Yazdanifard, R. (2015). What Internal and External Factors Influence Impulsive Buying Behaviour in Online Shopping? Global Journal of Management and Business Research, 15, 25-32.

Lindsay, P. H., \& Norman, D. A. (1972). Human Information Processing: An Introduction to Psychology. Academic Press.

Liu, D., Kumar, S., \& Mookerjee, V. S. (2012). Advertising Strategies in Electronic Retailing: A Differential Games Approach. Information Systems Research, 23, 903-917. https://doi.org/10.1287/isre.1110.0377

Liu, Y., Li, H., \& Hu, F. (2013). The Website Attributes in Urging Online Impulse Purchase: An Empirical Investigation on Consumer Perceptions. Decision Support Systems, 55, 829-837. https://doi.org/10.1016/j.dss.2013.04.001

Lo, L. Y. S., Lin, S. W., \& Hsu, L. Y. (2016). Motivation for Online Impulse Buying: A Two-Factor Theory Perspective. International Journal of Information Management, 36, 759-772. https://doi.org/10.1016/j.ijinfomgt.2016.04.012

Logan, K., Bright, L. F., \& Gangadharbatla, H. (2012). Facebook versus Television: Advertising Value Perceptions among Females. Journal of Research in Interactive Marketing, 6, 164-179. https://doi.org/10.1108/17505931211274651

MacKenzie, S. B., \& Lutz, R. J. (1989). An Empirical Examination of the Structural Antecedents of Attitude toward the Ad in an Advertising Pretesting Context. Journal of Marketing, 53, 48-65. https://doi.org/10.1177/002224298905300204

Madhavaram, S. R., \& Laverie, D. A. (2004). Exploring Impulse Purchasing on the Internet. ACR North American Advances, 31, 59-66.

Maiz, A., Arranz, N., \& de Arroyabe, J. C. F. (2016). Factors Affecting Social Interaction on Social Network Sites: The Facebook Case. Journal of Enterprise Information Management, 29, 630-649. https://doi.org/10.1108/JEIM-10-2014-0105

Mangold, W. G., \& Faulds, D. J. (2009). Social Media: The New Hybrid Element of the Promotion Mix. Business Horizons, 52, 357-365. https://doi.org/10.1016/j.bushor.2009.03.002

Matz, S. C., Kosinski, M., Nave, G., \& Stillwell, D. J. (2017). Psychological Targeting as an Effective Approach to Digital Mass Persuasion. Proceedings of the National Academy of Sciences of the United States of America, 114, 12714-12719. https://doi.org/10.1073/pnas.1710966114

McCarthy, J., Rowley, J., Ashworth, C. J., \& Pioch, E. (2014). Managing Brand Presence through Social Media: The Case of UK Football Clubs. Internet Research, 24, 181-204. https://doi.org/10.1108/IntR-08-2012-0154

Melason, D. (2012). Facebook Posts First Earnings as a Public Company: \$1.18 Billion in 
Revenue, 955 Million Users.

http://www.engadget.com/2012/07/26/facebook-posts-first-earnings-as-a-publiccompa ny-1-8-billion/

Mir, I. A. (2012). Consumer Attitudinal Insights about Social Media Advertising: A South Asian Perspective. The Romanian Economic Journal, 15, 265-288.

Mitchell, A. A., \& Olson, J. C. (1981). Are Product Attribute Beliefs the Only Mediator of Advertising Effects on Brand Attitude? Journal of Marketing Research, 18, 318-332. https://doi.org/10.1177/002224378101800306

Moorman, C., \& Day, G. S. (2016). Organizing for Marketing Excellence. Journal of Marketing, 80, 6-35. https://doi.org/10.1509/jm.15.0423

Mulky, A., Sarkar, A., \& Mukherjee, S. (2019). Key Drivers of Impulse Purchase Online: An Exploration in an Emerging Market (pp. 146-149).

Muntinga, D. G., Moorman, M., \& Smit, E. G. (2011). Introducing COBRAs: Exploring Motivations for Brand-Related Social Media Use. International Journal of Advertising, 30, 13-46. https://doi.org/10.2501/IJA-30-1-013-046

Murillo, E., Merino, M., \& Núñez, A. (2016). The Advertising Value of Twitter Ads: A Study among Mexican Millennials. Revista Brasileira de Gestão de Negócios, 18, 436-456.

Mussweiler, T., \& Strack, F. (2000). Numeric Judgments under Uncertainty: The Role of Knowledge in Anchoring. Journal of Experimental Social Psychology, 36, 495-518. https://doi.org/10.1006/jesp.1999.1414

Odoom, R., Anning-Dorson, T., \& Acheampong, G. (2017). Antecedents of Social Media Usage and Performance Benefits in Small- and Medium-Sized Enterprises (SMEs). Journal of Enterprise Information Management, 30, 383-399. https://doi.org/10.1108/JEIM-04-2016-0088

Okazaki, S. (2004). How Do Japanese Consumers Perceive Wireless Ads? A Multivariate Analysis. International Journal of Advertising, 23, 429-454. https://doi.org/10.1080/02650487.2004.11072894

Parboteeah, D. V., Valacich, J. S., \& Wells, J. D. (2009). The Influence of Website Characteristics on a Consumer's Urge to Buy Impulsively. Information Systems Research, 20, 60-78. https://doi.org/10.1287/isre.1070.0157

Parise, S., \& Guinan, P. J. (2008). Marketing Using Web 2.0. In Proceedings of the 41st Annual Hawaii International Conference on System Sciences (HICSS 2008) (pp. 281-281). IEEE. https://doi.org/10.1109/HICSS.2008.242

Park, E. J., Kim, E. Y., Funches, V. M., \& Foxx, W. (2012). Apparel Product Attributes Web Browsing and E-Impulse Buying on Shopping Websites. Journal of Business Research, 65, 1583-1589. https://doi.org/10.1016/j.jbusres.2011.02.043

Patino, A., Pitta, D. A., \& Quinones, R. (2012). Social Media's Emerging Importance in Market Research. Journal of Consumer Marketing, 29, 233-237.

https://doi.org/10.1108/07363761211221800

Petty, R. E., Unnava, R. H., \& Strathman, A. J. (1991). Theories of Attitude Change. In T. S. Robertson \& H. H. Kassarjian (Eds.), Handbook of Consumer Behaviour (pp. 241-280). Prentice-Hall.

Pickens, J. (2005). Attitudes and Perceptions. In Organizational Behavior in Health Care (pp. 43-75). Jones and Bartlett Publishers.

Pollay, R. W., \& Mittal, B. (1993). Here's the Beef: Factors, Determinants, and Segments in Consumer Criticism of Advertising. Journal of Marketing, 57, 99-114. https://doi.org/10.1177/002224299305700307 
Puntoni, S., Reczek, R. W., Giesler, M., \& Botti, S. (2021). Consumers and Artificial Intelligence: An Experiential Perspective. Journal of Marketing, 85, 131-151. https://doi.org/10.1177/0022242920953847

Quester, P., Neal, C., Pettigrew, S., Grimmer, M. R., Davis, T., \& Hawkins, D. (2007). Consumer Behaviour: Implications for Marketing Strategy. McGraw-Hill.

Rehman, F. U., Ilyas, M., Nawaz, T., \& Hyder, S. (2014). How Facebook Advertising Affects the Buying Behaviour of Young Consumers: The Moderating Role of Gender. Academic Research International, 5, 395-404.

Rook, D. W. (1987). The Buying Impulse. Journal of Consumer Research, 14, 189-199. https://doi.org/10.1086/209105

Rook, D. W., \& Fisher, R. J. (1995). Normative Influences on Impulsive Buying Behaviour. Journal of Consumer Research, 22, 305-313. https://doi.org/10.1086/209452

Rotzoll, D. A., Cunningham, S. J., \& Hogan, E. K. (1990). Evolution of MIDDS II in JSC space Shuttle Operations. Preprints, Seventh Int. Conf. on Interactive Information and Processing Systems for Meteorology, Oceanography, and Hydrology, New Orleans, LA, Amer. Meteor. Soc., 48-53.

Saxena, A., \& Khanna, U. (2013). Advertising on Social Network Sites: A Structural Equation Modelling Approach. Vision, 17, 17-25. https://doi.org/10.1177/0972262912469560

Senecal, S., \& Nantel, J. (2004). The Influence of Online Product Recommendations on Consumers' Online Choices. Journal of Retailing, 80, 159-169. https://doi.org/10.1016/j.jretai.2004.04.001

Sheth, J. N., \& Parvatiyar, A. (1995). The Evolution of Relationship Marketing. International Business Review, 4, 397-418. https://doi.org/10.1016/0969-5931(95)00018-6

Simon, H. A. (1957). Models of Man; Social and Rational. Wiley.

Solomon, M. R. (2004). Consumer Behaviour, Buying, Having and Being (6th ed.). Pearson Prentice Hall.

Stern, H. (1962). The Significance of Impulse Buying Today. Journal of Marketing, 26, 59-62. https://doi.org/10.1177/002224296202600212

Summers, C. A., Smith, R. W., \& Reczek, R. W. (2016). An Audience of One: Behaviorally Targeted Ads as Implied Social Labels. Journal of Consumer Research, 43, 156-178. https://doi.org/10.1093/jcr/ucw012

Summers, T. A., \& Hebert, P. R. (2001). Shedding Some Light on Store Atmospherics: Influence of Illumination on Consumer Behaviour. Journal of Business Research, 54, 145-150. https://doi.org/10.1016/S0148-2963(99)00082-X

Taylor, D. G., Lewin, J. E., \& Strutton, D. (2011). Friends, Fans, and Followers: Do Ads Work on Social Networks? How Gender and Age Shape Receptivity. Journal of Advertising Research, 51, 258-275. https://doi.org/10.2501/JAR-51-1-258-275

Tversky, A., \& Kahneman, D. (1974). Judgment under Uncertainty: Heuristics and Biases. Science, 185, 1124-1131. https://doi.org/10.1126/science.185.4157.1124

Verhagen, T., \& Van Dolen, W. (2011). The Influence of Online Store Beliefs on Consumer Online Impulse Buying: A Model and Empirical Application. Information \& Management, 48, 320-327. https://doi.org/10.1016/j.im.2011.08.001

Vonkeman, C., Verhagen, T., \& Van Dolen, W. (2017). Role of Local Presence in Online Impulse Buying. Information \& Management, 54, 1038-1048. https://doi.org/10.1016/j.im.2017.02.008

Wang, Y., \& Sun, S. (2010). Examining the Role of Beliefs and Attitudes in Online Advertising. International Marketing Review, 27, 87-107. 


\section{https://doi.org/10.1108/02651331011020410}

Wells, J. D., Parboteeah, V., \& Valacich, J. S. (2011). Online Impulse Buying: Understanding the Interplay between Consumer Impulsiveness and Website Quality. Journal of the Association for Information Systems, 12, 32-56. https://doi.org/10.17705/1jais.00254

Wu, L., Chen, K. W., \& Chiu, M. L. (2016). Defining Key Drivers of Online Impulse Purchasing: A Perspective of Both Impulse Shoppers and System Users. International Journal of Information Management, 36, 284-296. https://doi.org/10.1016/j.ijinfomgt.2015.11.015

Wu, L., Chiu, M. L., \& Chen, K. W. (2020). Defining the Determinants of Online Impulse Buying through a Shopping Process of Integrating Perceived Risk, Expectation-Confirmation Model, and Flow Theory Issues. International Journal of Information Management, 52, Article ID: 102099.

https://doi.org/10.1016/j.ijinfomgt.2020.102099

Xiang, L., Zheng, X., Lee, M. K., \& Zhao, D. (2016). Exploring Consumers' Impulse Buying Behaviour on Social Commerce Platform: The Role of Parasocial Interaction. International Journal of Information Management, 36, 333-347. https://doi.org/10.1016/j.ijinfomgt.2015.11.002

Xu, H., Zhang, K. Z., \& Zhao, S. J. (2020). A Dual Systems Model of Online Impulse Buying. Industrial Management \& Data Systems, 120, 845-861. https://doi.org/10.1108/IMDS-04-2019-0214

Zeng, F., Huang, L., \& Dou, W. (2009). Social Factors in User Perceptions and Responses to Advertising in Online Social Networking Communities. Journal of Interactive Advertising, 10, 1-13. https://doi.org/10.1080/15252019.2009.10722159

Zhang, J., \& Mao, E. (2016). From Online Motivations to Ad Clicks and Behavioural Intentions: An Empirical Study of Consumer Response to Social Media Advertising. Psychology \& Marketing, 33, 155-164. https://doi.org/10.1002/mar.20862

Zhang, K. Z., Xu, H., Zhao, S., \& Yu, Y. (2018). Online Reviews and Impulse Buying Behavior: The Role of Browsing and Impulsiveness. Internet Research, 28, 522-543. https://doi.org/10.1108/IntR-12-2016-0377

Zhou, Z., \& Bao, Y. (2002). Attitudes toward Web Advertising: Effects of Internet Motivation and Internet Ability. Advances in Consumer Research. Association for Consumer Research (U.S.), 29, 71-78.

Zuboff, S. (2019). The Age of Surveillance Capitalism: The Fight for a Human Future at the New Frontier of Power: Barack Obama's Books of 2019. Profile Books. 